\title{
Verificación de la isotropía del hormigón proyectado por vía húmeda
}

\section{Evaluation of isotropy in wet-mix sprayed concrete}

\author{
L. Agulló(*), T. García(*), A. Aguado(*), E. Yubero(*)
}

Recepción/Received: 05-II-07

Aceptación/Accepted: 09-VI-08

Publicado online/Online publishing: 22-VII-09

\section{RESUMEN}

Dadas las diferencias entre el hormigón de partida y el colocado, la evaluación de las propiedades de un hormigón proyectado, por vía húmeda o seca, se realiza mediante la extracción de testigos, evaluándose las propiedades mecánicas o deformacionales de forma uniaxial, según la dirección de la proyección. No obstante, son muchas las aplicaciones, como es el caso del sostenimiento en túneles, en las que esta disposición no representa la forma de trabajo principal del hormigón en la estructura. En el presente artículo se ha verificado que pueden existir diferencias en la resistencia a compresión y módulo de elasticidad del hormigón proyectado por vía húmeda, según la dirección de evaluación. Éstas van ligadas a la orientación que sufre el árido grueso como consecuencia de la puesta en obra del hormigón. Asimismo, el hormigón proyectado del estudio se ha dosificado utilizando como procedimiento de dosificación una propuesta metodológica, basada en las diferencias entre hormigón colocado y de partida, en contraposición a los métodos habituales de dosificación que se fundamentan en la experiencia.

Palabras clave: hormigón proyectado, vía húmeda, resistencia a compresión, módulo de elasticidad, isotropía.

\section{SUMMARY}

It is well known that there are differences between the fresh mix concrete and the placed concrete sprayed using dry or wet-mix process. Because of that, the characterization of such material is carried out in cores extracted parallel to the spray direction from sample panels. However, in many applications (e.g. tunnel lining), considerable compressive stresses appear along the transversal direction. In this paper different spayed concretes are evaluated. It was observed that the values of compressive strength and modulus of elasticity were different depending on the direction of measurement. These differences are related to a preferential orientation of the coarse aggregate due to the characteristics of the casting process. Rather than applying classic empirical methods, the concrete mixes used in this study were designed according to a new proportioning method based on the difference between the composition of the fresh mix concrete and the placed concrete.

Keywords: sprayed concrete, wet-mix, compressive strength, module of elasticity, isotropy.

(*) Universidad Politécnica de Cataluña (Barcelona, España). 


\section{INTRODUCCIÓN}

Como es bien conocido, en la proyección del hormigón el material se lanza a gran velocidad sobre el soporte, operación que incluye dos etapas del hormigonado tradicional, la colocación y la compactación. Ello induce en el material colocado características propias que se manifiestan, fundamentalmente, en diferencias en la composición entre hormigón de partida y colocado, como consecuencia del rebote diferencial de los distintos componentes del hormigón y de la incorporación de aire asociada a la utilización del mismo como medio de transporte y colocación del hormigón.

Estas singularidades no sólo afectan al material y la economía de la obra, sino que también tiene repercusiones en el control, que se encarece y dificulta por la necesidad de la extracción de testigos para la evaluación del hormigón; asimismo, también incide en su dosificación, que se caracteriza por la falta de procedimientos analíticos, estando los métodos actuales basados en recomendaciones fundamentadas en la experiencia, Fernández Cánovas (1). Alternativas a estos procedimientos son las propuestas, válidas tanto para aplicaciones por vía húmeda como por vía seca, de Prudencio (2) y Rodríguez (3), esta última, basada en las diferencias existentes entre el hormigón colocado y el de partida, obteniendo la dosificación de partida aplicando al hormigón colocado la variación por la colocación.

Los estudios en el campo del hormigón proyectado se han orientado, principalmente, hacia el análisis del rebote, propiedades del material y utilización de nuevos componentes, como el humo de sílice o las fibras, entre otros (4). En este sentido, al igual que en el control, es usual extraer y ensayar los testigos según la dirección de la proyección de las artesas de control (5); así, posteriormente se ensaya el hormigón frente a una compresión uniaxial según la misma dirección en la que se ha proyectado la artesa. Sin embargo, resulta también de interés conocer el comportamiento del material frente a compresión uniaxial, según la dirección perpendicular a la de la proyección, dado que este comportamiento, como es el caso de sostenimiento en túneles, puede aproximarse más a la forma de trabajo del hormigón colocado en la estructura.

Asimismo, la consideración del comportamiento en ambas direcciones (paralela y transversal a la proyección) puede también, entre otros aspectos, aportar un mayor conocimiento sobre la influencia en las características del hormigón derivada de la propia orientación en los componentes del hormigón que supone el propio proceso de proyección $(6,7)$. Estos comportamientos, desde un punto de vista conceptual, los señala la ASA (8), si bien no los cuantifica.

\section{INTRODUCTION}

It is well known that sprayed concrete can be defined as a concrete projected at high velocity onto a surface. This operation comprises two steps from conventional concrete use: casting and compaction. It confers unique characteristics to the applied material, which primarily manifest themselves in differences in composition between initial and cast concrete. These result from varying degrees of rebound undergone by the components of the concrete as well as from incorporation of air, which is used as both propulsion medium and casting agent for the initial concrete.

These differences affect not only the material and the cost of the construction project, but also have implications for quality control, which becomes costlier and more complicated because concrete cores must be extracted for evaluation. Likewise, they also affect dosing, for which analytical procedures are lacking, and which are consequently based on experience (Fernández Cánovas (1)). Alternative methods, for wet-mix and drymix processes, are proposed by Prudencio (2) and Rodríguez (3), the latter of which is based on differences between initial and cast concrete, whereby the initial mix is obtained by applying the variation by casting to the cast concrete.

Studies on sprayed concrete have primarily emphasised rebound analysis, material properties, and the use of new components such as fibres and silica fume (4). As with quality control, in these studies the compressive strength is obtained in cores extracted parallel to the spray direction from sprayed panels (5). However, in many applications, as in tunnel lining, considerable compressive stresses appear along the transversal direction, where the behaviour of concrete is extremely complicate to evaluate.

Likewise, considering the behaviour in each direction (parallel to or perpendicular to the spray) can also provide better information on how reorientation of the concrete components caused by the spraying affects the concrete (6 and 7). The ASA (8) refers to these behaviours from a conceptual point of view, but does not quantify them. 
En el marco de estas consideraciones, los objetivos del estudio que se presenta en este artículo son dos:

- Evaluación en términos mecánicos y deformacionales, resistencia a compresión y módulo de elasticidad en compresión, de la posible anisotropía del hormigón proyectado por vía húmeda, planteándose para ello dos dosificaciones: una, utilizada en el sostenimiento de un túnel y otra, obtenida a partir de la metodología propuesta (3) y (6) aplicada a los mismos componentes. En este sentido se ha considerado la posibilidad de incorporar o no humo de sílice a la mezcla en ambos casos.

- Evaluación y validación del procedimiento de dosificación propuesto para mezclas proyectadas por vía húmeda, mediante la comparación de las propiedades del material resultante respecto a las del hormigón utilizado en la construcción del túnel.

\section{PROPUESTA METODOLÓGICA DE DOSIFICACIÓN}

La propuesta metodológica de dosificación utilizada se fundamenta en las modificaciones que el propio sistema de proyección introduce en la composición del hormigón de partida (hormigón suministrado por la planta y que se introduce en la bomba para ser proyectado) frente al hormigón colocado (hormigón proyectado adherido al soporte).

Estas modificaciones son consecuencia, por una parte, del rebote, que será diferente para cada componente, aumentando con el tamaño de partícula, lo que significa una modificación del esqueleto granular de partida y, por otra parte, de la incorporación de aire como sistema de transporte y colocación, traduciéndose en una mayor porosidad en el hormigón colocado. Partiendo de este principio, se considera el hormigón colocado como el hormigón de partida modificado por el sistema de colocación:
Having considered these factors, two objectives were established for the study described here:

- Mechanical and deformational evaluation (compressive strength and modulus of elasticity) of possible anisotropy in wet-mix sprayed concrete. Two mixes have been studied: one used for tunnel lining ( 3 and $6)$, and one designed according to a new method for proportioning dry-mix and wet-mix concrete applied to the same components. In both cases, incorporation of silica fume was considered as an option.

- Evaluation and validation of the dosing procedure proposed for wet-mix sprayed concrete through comparative analysis of the material properties of this concrete and of the concrete used for constructing the tunnel.

\section{PROPOSED PROPORTIONING METHOD}

The proposed proportioning method is based on differences between the composition of the initial concrete (the fresh concrete) and that of the cast concrete (sprayed concrete placed on the support), that are caused by the spraying system itself.

These modifications resulted of rebound, which affects each component to a different extent, increasing with particle size and leading to changes in the starting granular skeleton. They are also down to incorporation of air, which is used as both transport and casting medium, which leads to greater porosity placed concrete. According to this principle, cast concrete can be defined as the initial concrete modified by the spraying process:
Con este planteamiento se obtiene la siguiente formulación [1] que relaciona la cantidad de un componente $X$ en el hormigón colocado $\left(X_{c}\right)$ y de partida $\left(X_{p}\right)$ a partir de su respectivo coeficiente de rebote $\left(r_{x}\right)$, el coeficiente de rebote medio del hormigón $\left(r_{m}\right)$ y las densidades del hormigón colocado $\left(\gamma_{c}\right)$ y de partida $\left(\gamma_{p}\right)$ :
This is used as the basis for the following formula [1], which relates the quantities of a component $X$ in the placed concrete $\left(X_{c}\right)$ and in the initial concrete $\left(X_{p}\right)$ according to the rebound coefficient corresponding to this component $\left(r_{x}\right)$, the average rebound coefficient for the concrete $\left(r_{m}\right)$ and the densities of the placed concrete $\left(\gamma_{c}\right)$ and of the initial concrete $\left(\gamma_{p}\right)$ :

$$
X_{c}=\left(1-r_{X}\right) \cdot X_{p} \cdot \frac{1}{1-r_{m}} \cdot \frac{\gamma_{c}}{\gamma_{p}}
$$


La metodología de dosificación se articula en torno a tres etapas: evaluación de las modificaciones que el sistema de puesta en obra introduce en el hormigón; definición del hormigón colocado teniendo en cuenta las prestaciones requeridas; y determinación de la composición del hormigón de partida a partir de la composición del hormigón colocado y aplicando las modificaciones por la puesta en obra determinadas en la primera etapa del proceso. Los fundamentos teóricos de este planteamiento, así como el detalle de la estimación de los distintos parámetros que configuran la metodología pueden consultarse en las referencias (3) y (6).

En la Tabla 1 se exponen los resultados de la aplicación de esta metodología de dosificación a los materiales componentes utilizados en los hormigones proyectados del presente estudio. En la misma puede verse, tal como se ha dicho, que los coeficientes de rebote aumentan a medida que aumenta el tamaño del árido, habiéndose considerado un rebote medio del $10,4 \%$, en el entorno de los valores usuales en vía húmeda para este tipo de aplicación (túneles con robot). Asimismo, los valores de los pesos del hormigón, tanto de partida $\left(2.415 \mathrm{~kg} / \mathrm{m}^{3}\right)$ como colocado $\left(2.206 \mathrm{~kg} / \mathrm{m}^{3}\right)$, están en los valores usuales.
The proportioning method is centred on three steps: evaluation of the changes that the spray system induces in the concrete; definition of placed concrete according to requirements; and definition of the composition of initial concrete based on that of the placed concrete and according to the changes identified in the first step. The theoretical basis of this approach, as well as details of the calculation of the parameters implied, are provided in (3) and (6).

Table 1 lists the results of applying this proportioning method to the constituent materials of the sprayed concretes used in this study. It shows that, as previously mentioned, the rebound coefficients increase in function of the aggregate size. The mean rebound coefficient considered was $10.4 \%$, which is standard for wet-mix process applications (tunnels using concrete spraying robot). Likewise, the values for the Specific weight of the initial concrete $\left(2415 \mathrm{~kg} / \mathrm{m}^{3}\right)$ and of the placed concrete $\left(2206 \mathrm{~kg} / \mathrm{m}^{3}\right)$ are within the normal range.

Tabla 1 / Table 1

Dosificación del hormigón colocado y de partida (*SSS: Superficie Seca Saturada).

Mix proportions of inicial concrete and of placed concrete ( ${ }^{*} S S D$ : Saturated Surface-Dry).

\begin{tabular}{|c|c|c|c|c|}
\hline \multicolumn{2}{|c|}{ Componentes / Components } & $\begin{array}{c}\text { Coeficiente de rebote / } \\
\text { Rebound coefficients }\end{array}$ & $\begin{array}{l}\text { Hormigón de partida } \\
\left(\text { en } \mathbf{k g} / \mathrm{m}^{3}\right) / \text { Inicial } \\
\left.\text { concrete (in } \mathrm{kg} / \mathrm{m}^{3}\right)\end{array}$ & $\begin{array}{c}\text { Hormigón colocado } \\
\left(\mathrm{en} \mathbf{k g} / \mathrm{m}^{3}\right) / \\
\left.\text { Cast concrete (in } \mathrm{kg} / \mathrm{m}^{3}\right)\end{array}$ \\
\hline \multicolumn{2}{|c|}{ Cemento / Cement } & 0.05 & 410 & 397 \\
\hline \multicolumn{2}{|c|}{ Agua / Water } & 0.07 & 150 & 143 \\
\hline \multirow{3}{*}{$\begin{array}{l}\text { Áridos *SSS / } \\
\text { *SSD Aggregate }\end{array}$} & Arena/Sand $0 / 3$ & 0.06 & 145 & 139 \\
\hline & Arena/Sand 0/6 & 0.08 & 1245 & 1167 \\
\hline & Gravilla/Gravel 6/12 & 0.24 & 465 & 360 \\
\hline \multicolumn{3}{|c|}{ Suma / Sum } & 2415 & 2206 \\
\hline \multicolumn{3}{|c|}{ Coeficiente medio de rebote / Mean rebound coefficient } & \multicolumn{2}{|c|}{$r_{m}=0.104(10.4 \%)$} \\
\hline
\end{tabular}

\section{DOSIFICACIONES Y PUESTA EN OBRA}

Los materiales utilizados en la proyección corresponden a los utilizados habitualmente en la proyección por vía húmeda en la construcción de un túnel. El esqueleto granular está constituido a partir de tres fracciones de árido, una gravilla $6 / 12 \mathrm{~mm}$, una arena $0 / 6 \mathrm{~mm}$ y una arena lavada $0 / 3 \mathrm{~mm}$. La fracción $0 / 3$ es una arena correctora natural de río, mientras que las otras dos fracciones proceden de una planta de machaqueo.

Dada la importancia que los husos granulométricos tienen en los sistemas empíricos de dosificación, en la Tabla 2 se presentan las granulometrías así como las densidades del árido saturado superficie seca de las tres fracciones granulométricas consideradas.

\section{MIX PROPORTIONS AND CONSTRUCTION}

The materials used in this study correspond to those typically used for wet-mix spraying in tunnel construction. The granular skeleton is comprised of three fractions of aggregate: washed sand ( 0 to $3 \mathrm{~mm}$ ), sand ( 0 to $6 \mathrm{~mm}$ ) and gravel ( 6 to $12 \mathrm{~mm}$ ). The first fraction is natural correcting sand from a river, whereas the other two are from a crushing plant.

Given the importance of grading envelopes in empirical dosing systems, the values for the aggregate grading as well as those for the densities of the saturated surface-dry (SSD) aggregate in the three aggregate grade fractions considered have been listed in Table 2. 
Tabla 2 / Table 2

Granulometría de los áridos.

Aggregate grading of the three fractions.

\begin{tabular}{|c|c|c|c|c|}
\hline \multicolumn{2}{|c|}{ Áridos / Aggregate } & Gravilla / Gravel 6/12 & Arena / Sand 0/6 & Arena / Sand 0/3 \\
\hline \multicolumn{2}{|c|}{ Granulometría / Aggregate grading } & \multicolumn{3}{|c|}{ Porcentaje de árido que pasa / Percentage of agrégate that passes } \\
\hline \multirow{10}{*}{$\begin{array}{c}\emptyset \text { tamiz }(\mathrm{mm}) / \\
\text { sieve }(\mathrm{mm})\end{array}$} & 16.00 & 99.0 & 100.0 & 100.0 \\
\hline & 12.50 & 98.0 & 100.0 & 100.0 \\
\hline & 8.00 & 58.0 & 99.0 & 100.0 \\
\hline & 4.00 & 12.0 & 75.0 & 99.0 \\
\hline & 2.00 & 7.0 & 52.0 & 97,0 \\
\hline & 1.00 & 6.0 & 36.0 & 94.0 \\
\hline & 0.50 & 2.8 & 26.0 & 75.0 \\
\hline & 0.25 & 2.8 & 19.0 & 30.0 \\
\hline & 0.125 & 2.8 & 14.0 & 5.0 \\
\hline & 0.063 & 2.8 & 11.0 & 0.5 \\
\hline \multicolumn{2}{|c|}{ Densidad árido SSS / Density of SSD aggregate } & $2.67 \mathrm{~kg} / \mathrm{m}^{3}$ & $2.64 \mathrm{~kg} / \mathrm{m}^{3}$ & $2.65 \mathrm{~kg} / \mathrm{m}^{3}$ \\
\hline
\end{tabular}

El cemento utilizado es del tipo I 52,5 R y el humo de sílice ha sido suministrado, en forma densificada, en sacos de $20 \mathrm{~kg}$. Para conseguir una consistencia adecuada, se ha utilizado un aditivo superfluidificante tipo naftaleno y en la boquilla de proyección del robot se incorpora un acelerante basado en aluminatos.

Con estos componentes se han proyectado en obra cuatro hormigones (resistencia a compresión media de 30 MPa a 28 días), dos correspondientes a la dosificación de obra y otros dos resultantes de la aplicación de propuesta metodológica de dosificación incorporando humo de sílice como adición, sustituyendo el $8 \%$ en peso del cemento, orden de magnitud usual en este tipo de aplicaciones:

- H1: Dosificación patrón, utilizada en la construcción del túnel.

- H2: En base a la dosificación patrón, incorporar humo de sílice.

- H3: Dosificación resultante de aplicar la propuesta metodológica.

- H4: Dosificación resultante de aplicar la propuesta metodológica incorporando humo de sílice.

En la Tabla 3 se detallan las dosificaciones de las cuatro mezclas, donde las cantidades de árido que figuran corresponden a condiciones de árido saturado superficie seca. Cabe observar que para mantener un flujo de material homogéneo y evitar un bombeo intermitente la dosis de superplastificante se ha incrementado en las mezclas que incluyen el humo de sílice en su composición.

La fabricación del hormigón se realizó en la planta ubicada en la obra, en amasadas de dos metros cúbicos. En los hormigones con humo de sílice, la incorporación de la adición a la amasadora se realizó, previo pesado de la misma, manualmente en el momento de la incorporación del cemento.
The cement used is Type I $52.5 \mathrm{R}$. The silica fume used was added in condensed form in $20 \mathrm{~kg}$ bags. To obtain the desired consistency, a naphthalene-type superplasticizer additive was used, and an aluminate-based accelerant was added at the nozzle of the robot.

Using these components, four mixes (mean compressive strength at 28 days: $30 \mathrm{MPa}$ ) were sprayed: two corresponding to the construction mix; and two based on the proposed proportioning method, silica fume was added at $8 \%$ of cement weight as substitution of cement, a typical value for these applications.

- C1: Reference mix (used for construction of the tunnel);

- C2: Reference mix adding silica fume;

- C3: Mix based on proposed proportioning method;

- C4: Mix based on proposed method adding silica fume;

Table 3 summarises the mixes of the four concretes, whereby the quantities of aggregate shown correspond to SSD aggregate. It should be noted that, in order to maintain a homogeneous flow of material and avoid intermittent pumping, a greater dose of superplasticizer was used for the mixes containing silica fume.

The concrete was mixed on-site in batches of $2 \mathrm{~m}^{3}$. For concrete containing silica fume, the fume was first weighed, and then added manually to the batch at the time of cement addition. The transport time from the mixing plant to the application point was approximately 
Tabla 3 / Table 3

Dosificaciones teóricas contempladas en el estudio. Theoretical concrete mixes considered.

\begin{tabular}{|c|c|c|c|c|}
\hline Materiales / Materials $\left(\mathrm{kg} / \mathrm{m}^{3}\right)$ & $\mathrm{H1} / \mathrm{C1}$ & $\mathrm{H2} / \mathrm{C2}$ & H3 / C3 & H4 / C4 \\
\hline Cemento / Cement I52,5R & 425 & 390 & 410 & 376 \\
\hline Agua / Water $\left(1 / \mathrm{m}^{3}\right)$ & 179 & 179 & 150 & 150 \\
\hline Arena / Sand 0/3 mm & 348 & 348 & 145 & 145 \\
\hline Arena / Sand 0/6 mm & 1184 & 1184 & 1245 & 1245 \\
\hline Grava / Gravel 6/12 mm & 295 & 295 & 465 & 465 \\
\hline Microsílice / Microsilica & 0 & 35 & 0 & 34 \\
\hline Superplastificante / Superplasticizer $\left(1 / \mathrm{m}^{3}\right)$ & 8 & 9 & 8 & 10 \\
\hline Acelerante / Accelerator $\left(1 / \mathrm{m}^{3}\right)$ & 12 & 12 & 12 & 12 \\
\hline
\end{tabular}

El tiempo de transporte desde la planta hasta el punto de aplicación fue aproximadamente de diez minutos, parte del cual transcurre en el interior del túnel (aprox. 800 metros).

Para cada dosificación se proyectaron un total de cuatro artesas según norma UNE 83602 (9), de las cuales dos se destinaron al estudio bidireccional de resistencia y rigidez. Todas las proyecciones se realizaron en el mismo día en un intervalo de tiempo de cuatro horas, aproximadamente. Dadas las dificultades y para evitar interferencias en la obra el rebote durante la proyección únicamente se evaluó cualitativamente de forma visual. Fruto de las actuaciones presenciadas en la puesta en obra de los distintos hormigones proyectados cabe plantear una serie de reflexiones desde una óptica fundamentalmente cualitativa.

Con respecto al bombeo y proyección de las mezclas, las cuatro mezclas han mostrado una correcta aptitud para su puesta en obra con los medios disponibles. En relación al rebote, las dosificaciones sin humo de sílice, si bien sin diferencias muy significativas, se apreció un mayor rebote en la dosificación $\mathrm{H} 3$ resultante de la propuesta metodológica que en la $\mathrm{H} 1$ correspondiente al hormigón de referencia utilizado en la obra. Ello puede estar justificado por la mayor cantidad de áridos de fracción gruesa presentes en la dosificación $\mathrm{H} 3$ frente a los presentes en la $\mathrm{H} 1$. Asimismo, en las dosificaciones $\mathrm{H} 2$ y $\mathrm{H} 4$, ambas con humo de sílice, el rebote apreciado parece ser algo menor que en las dosificaciones $\mathrm{H} 1$ y $\mathrm{H} 3$, siendo quizás la dosificación H4 (propuesta metodológica + humo de sílice), la que ha presentado un menor rebote.

\section{CAMPAÑA EXPERIMENTAL Y RESULTADOS}

\subsection{Preparación de las muestras}

La extracción de los testigos de las artesas para la campaña experimental se ha realizado según los procedimientos de la norma UNE 83605 (10). El proceso de obtención y preparación de las muestras de ensayo es el siguiente:
10 minutes, part of which passed inside the tunnel (ca. 800 meters).

Four panels were shot for each mix according to standard UNE 83602 (9), two of which were employed for bidirectional study of strength and rigidity. All sprayed concretes were applied on the same day in a window of time of ca. 4 hours. Given the inherent difficulties of this work, and in order not to disturb the staff, rebound was only analysed visually. Based on these observations, a series of primarily qualitative conclusions was reached.

All four mixes performed adequately under the test conditions in terms of the pump and spraying. In terms of rebound, for the mixes lacking silica fume, C3 (the mix based on the proposed method) showed slightly greater rebound than $\mathrm{C} 1$ (the reference mix). This can be rationalised by the higher proportion of coarse aggregate. The mixes containing silica fume (C2 and C4) appeared to suffer less rebound than $\mathrm{C} 1$ or $\mathrm{C} 3$, whereby C4 (the mix based on the proposed proportioning method and containing silica fume) seemed to undergo the least rebound.

\section{EXPERIMENTAL PROGRAM AND RESULTS}

\subsection{Preparation of test specimens}

Concrete cores for the experimental program were extracted according to standard UNE 83605 (10). The process to obtain and prepare them comprised the following: 
- En primer lugar, y para facilitar la extracción de los testigos en la dirección transversal a la de proyección, se ha procedido al corte de las artesas proyectadas mediante sierra circular, obteniéndose dos fragmentos de artesa, para la extracción de los testigos en ambas direcciones.

- De los dos fragmentos se procedió a la extracción de los testigos, de $74 \mathrm{~mm}$ de diámetro, obteniéndose un mínimo de 4-5 testigos en cada dirección (Figura 1).
- Firstly, and in order to facilitate extraction of the cores in the perpendicular direction to the spraying, the panels were cut in two fragments using a circular saw.

- A minimum of four to five cores (74 $\mathrm{mm}$ in diameter) were extracted from these fragments (Figure 1).

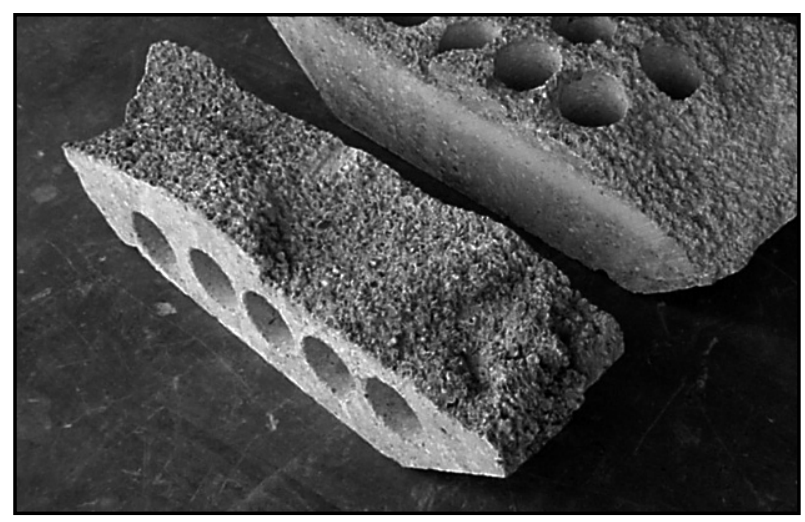

Figura 1. Fragmentos obtenidos del corte de la artesa con los testigos extraídos.

Figure 1. Fragments obtained by cutting the mortar carrier, shownafter simples had been removed.

- Corte de los extremos del testigo, mediante sierra circular, intentando obtener probetas de esbeltez 2 (longitud de $150 \pm 2 \mathrm{~mm}$ de longitud), con un refrentado posterior de ambas caras de la probeta.

Los ensayos se han realizado a los 90 días de la proyección, manteniéndose todas las artesas y testigos en las mismas condiciones termohigrométricas, durante la primera semana en el interior del túnel y hasta la fecha de ensayo a temperatura y humedad ambiental. En la Tabla 4 se detalla la programación de ensayos.
- The ends of each core were cut by circular saw trying to obtain test specimens with slenderness 2 (length of $150 \pm 2 \mathrm{~mm}$ ). The specimens were then capped at each face.

The tests were performed at the age of 90 days. All panels and samples were maintained under the same thermohygrometric conditions: they were kept inside the tunnel during the first week, and then at ambient temperature and humidity until the testing date. The testing schedule are summarised in Table 4.

Tabla 4 / Table 4

Programación de ensayos.

Testing schedule.

\begin{tabular}{|c|c|c|c|c|c|}
\hline \multirow{2}{*}{$\begin{array}{c}\text { Dosificación / } \\
\text { Mix }\end{array}$} & \multirow{2}{*}{$\begin{array}{c}\text { Número artesas / } \\
\text { Number of mortar } \\
\text { carriers }\end{array}$} & \multicolumn{2}{|c|}{ Paralelo a la proyección / Parallel to spray } & \multicolumn{2}{|c|}{$\begin{array}{c}\text { Transversal a la proyección / } \\
\text { Perpendicular to spray }\end{array}$} \\
\cline { 3 - 6 } & & $\begin{array}{c}\text { Compresión / } \\
\text { Compression }\end{array}$ & Módulo / Module & $\begin{array}{c}\text { Compresión / } \\
\text { Compression }\end{array}$ & Módulo / Module \\
\hline $\mathrm{H} 1 / C 1$ & 2 & 4 & 5 & 4 & 5 \\
\hline $\mathrm{H} 2 / C 2$ & 3 & 6 & 7 & 6 & 8 \\
\hline $\mathrm{H} 3 / \mathrm{C3}$ & 2 & 4 & 6 & 4 & 4 \\
\hline $\mathrm{H} 4 / C 4$ & 2 & 4 & 5 & 4 & 4 \\
\hline
\end{tabular}

\subsection{Resultados experimentales}

En la Tabla 5 se presentan los valores medios y coeficiente de variación de la resistencia a compresión y

\subsection{Experimental results}

Table 5 lists the mean values and coefficient of variation for the compressive strength and modulus of elasticity of 
módulo de elasticidad en compresión de los cuatro hormigones en la dirección paralela y transversal a la proyección, que se han representado de forma gráfica en la Figura 2 (resistencia a compresión) y Figura 3 (módulo de elasticidad).

Con respecto a la resistencia a compresión, puede observarse que en los cuatro hormigones estudiados las resistencias medias obtenidas en la dirección paralela son mayores que las obtenidas en la dirección transversal, si bien, en términos cuantitativos, las diferencias son pequeñas en el caso de las mezclas $\mathrm{H} 1$ y $\mathrm{H} 2$, mientras que para las dosificaciones $\mathrm{H} 3$ y $\mathrm{H} 4$, que recordemos presentan mayor porcentaje de árido grueso en la mezcla, es más acusada. the four concretes in both directions (parallel and perpendicular to the spray). These values are plotted in Figure 2 (compressive strength) and Figure 3 (modulus of elasticity).

In terms of compressive strength, for all four concretes the values are greater in the parallel direction than in the perpendicular direction. Quantitatively, the differences are rather small for $C 1$ and $C 2$, whereas for $C 3$ and $C 4$ -which, as explained above, contain a higher proportion of coarse aggregate- the differences are more pronounced.

Tabla 5 / Table 5

Caracterización del hormigón endurecido.

Characterization of the hardened concrete.

\begin{tabular}{|c|c|c|c|c|c|}
\hline \multicolumn{2}{|c|}{ Dosificación / Mix } & H1 / C1 & H2 / C2 & H3 / C3 & H4 / C4 \\
\hline \multirow{4}{*}{$\mathrm{f}_{\mathrm{cm}}$} & Paralela / & 34.8 & 40.5 & 33.2 & 47.2 \\
$\mathrm{MPa}$ & Parallel & $(13.1 \%)$ & $(14.7 \%)$ & $(9.3 \%)$ & $(7.9 \%)$ \\
\cline { 2 - 6 } & Transversal / & 34.1 & 40.0 & 30.0 & 36.7 \\
& Perpendicular & $(8.3 \%)$ & $(7.9 \%)$ & $(11.6 \%)$ & $(19.5 \%)$ \\
\hline \multirow{4}{*}{$\mathrm{EPa}$} & Paralela / & 26.5 & 27.4 & 25.3 & 27.4 \\
& Parallel & $(8.3 \%)$ & $(6.3 \%)$ & $(13.7 \%)$ & $(8.1 \%)$ \\
\cline { 2 - 6 } & Transversal / & 28.9 & 26.8 & 26.7 & 28.6 \\
& Perpendicular & $(7.1 \%)$ & $(14.9 \%)$ & $(5.1 \%)$ & $(11.9 \%)$ \\
\hline
\end{tabular}

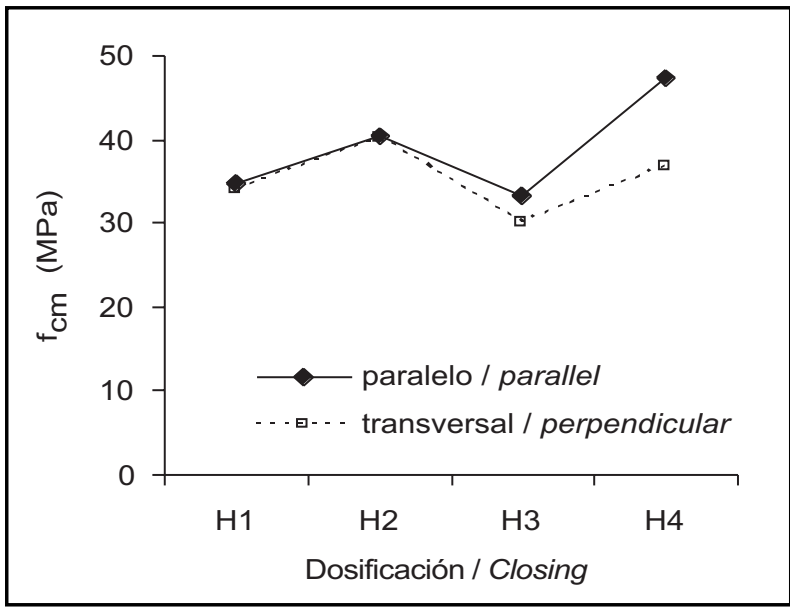

Figura 2. Resistencia a compresión. Figure 2. Compressive strength.

Teniendo en cuenta que para cada dosificación no existen diferencias en cuanto a composición en una y otra dirección, como primera hipótesis argumental se planteó la existencia de cierta predominancia en la orientación del árido grueso en una de las direcciones, aspecto que sí puede afectar a la resistencia del hormigón

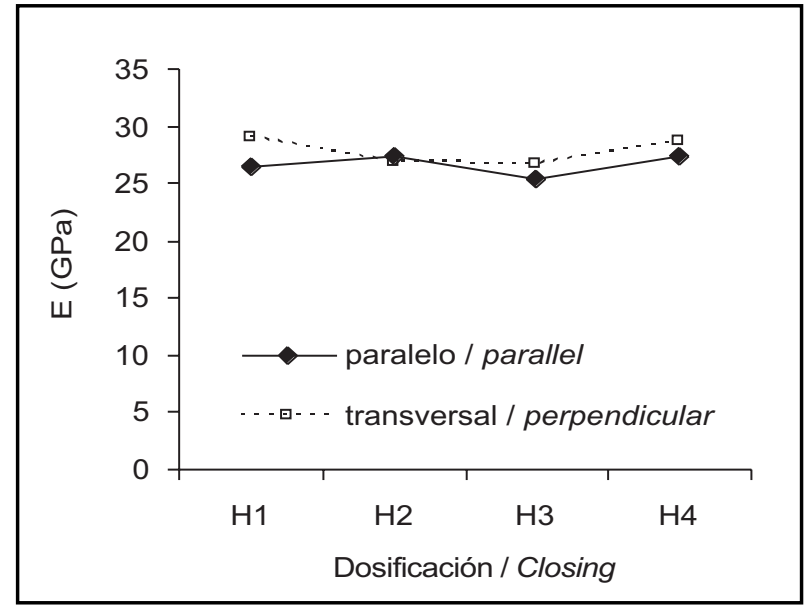

Figura 3. Módulo de elasticidad. Figure 3. Modulus of elasticity.

Considering that no differences in composition between the two directions there are not, it was first proposed that a preferential orientation of the coarse aggregate could affect the concrete strength in function of the direction of measurement. Therefore, if the compressive strength is tested parallel to the aggregate, then cracks between the 
según la dirección de evaluación. En este sentido, si la compresión se realiza en la dirección de orientación se facilita la evolución de la fisura entre interfase y árido, repercutiendo de forma negativa en la resistencia del material, mientras que si es transversal a la orientación, la disposición del árido dificulta la propagación de la fisura, ya que ésta debe atravesar o bordear el árido. Para evaluar este efecto se determinó la orientación predominante de las partículas más susceptibles de sufrir una orientación determinada, es decir, las lajas y agujas a partir de un cierto tamaño, que en nuestro caso se ha considerado $10 \mathrm{~mm}$ (Figura 4), contabilizando el número de áridos del perímetro del testigo dispuestos en la dirección longitudinal, transversal y diagonal a la proyección. interface and the preferential orientation of aggregate would be facilitated, consequently having detrimental effects on the strength of the concrete. Contrariwise, if the test is performed perpendicular to the preferential orientation of aggregate, said cracks would be more difficult to form, as they would have to cross or bypass the aggregate. To study this effect, the main orientation of the particles most susceptible being oriented was determined. Specifically, these comprise flaky and elongated of a minimum size, which for this study was considered to be $10 \mathrm{~mm}$ (see Figure 4). The aggregates from the perimeter sample were counted according to their orientation: parallel, perpendicular or diagonal to the spray direction.

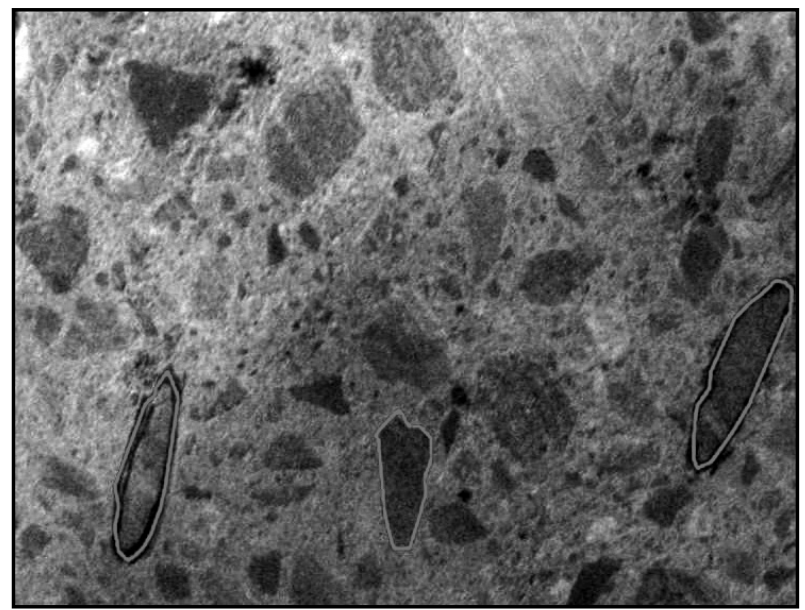

Figura 4. Detalle de la orientación de los áridos.

Figure 4. Close-up of the orientation of the aggregates.

Los resultados de la inspección visual apoyan la argumentación anterior. En las dosificaciones $\mathrm{H} 1$ y H2, con menor presencia de árido grueso y diferencias mínimas en resistencia según la dirección de evaluación, no se reflejan alteraciones significativas en la orientación de los áridos; por el contrario, en las mezclas H3 y $\mathrm{H} 4$, se detecta un mayor número de partículas orientadas en la dirección transversal a la de proyección. Atendiendo a que en el bombeo, durante el transporte del hormigón, el árido se orientará en el sentido del flujo, es en el momento del impacto de la partícula con el soporte cuando se produce el cambio en la orientación de las partículas gruesas. En este sentido, la influencia en las mezclas $\mathrm{H} 1$ y $\mathrm{H} 2$ es menor, dado el menor contenido de árido grueso en la composición. Por último, mencionar que las diferencias en resistencia entre ambas direcciones dependerán de las características del árido, y en especial, de su coeficiente de forma, esperándose rangos mayores en áridos de coeficientes de forma bajos (predominio de partículas en lajas frente a esféricas).
The aforementioned argument is supported by the results of the visual inspection. Mixes $C 1$ and $C 2$, which have less coarse aggregate and do not exhibit any marked differences based on measurement direction, do not show any significant differences in the orientation of their aggregates. In contrast, mixes C3 and $\mathrm{C} 4$ have a greater number of particles perpendicular to the spray direction. Hence, the composition of the mixes $C 1$ and $C 2$ has less effect on compressive strength, given their lower proportion of coarse aggregate. The differences in strength between the two directions depend on the characteristics of the aggregate, especially the shape coefficient: greater strength correlates with a lower shape coefficient. 
Cabe destacar el incremento de la resistencia de las mezclas que incluyen humo de sílice en su composición ( $\mathrm{H} 2$ con respecto $\mathrm{H} 1$ y $\mathrm{H} 4$ con respecto $\mathrm{H} 3$ ), que se sitúa en torno al $20 \%$.

Con respecto al módulo (Figura 3), la tendencia es contraria a la observada en la resistencia a compresión. Excepto para la mezcla $\mathrm{H} 2$, donde prácticamente los valores en una y otra dirección coinciden, los módulos evaluados en la dirección transversal a la proyección son mayores respecto a los evaluados en la longitudinal, si bien, en términos cuantitativos, las diferencias entre estos módulos en las dos direcciones son muy pequeñas para los hormigones, cuatro hormigones (inferiores a $1 \mathrm{GPa})$, lo cual pone de manifiesto una influencia menos significativa. Estos resultados estarían en consonancia con la hipótesis de orientación, ya que si el árido se orienta de forma transversal a la proyección, cabe esperar módulos mayores en esa dirección.

En cuanto a las prestaciones del material, las resistencias a compresión y módulos evaluados en las mezclas obtenidas a partir del procedimiento son similares a las obtenidas en las de referencia, a pesar de reducir en 15 $\mathrm{kg}$ la cantidad de cemento, aspecto que debe atribuirse a la optimización de su dosificación, y en especial a un esqueleto granular más compacto.

\subsection{Análisis estadístico}

Con el fin de definir qué hormigones presentan diferencias significativas en sus propiedades según la dirección de evaluación, se ha planteado un análisis estadístico basado en la comparación de las diferencias de las medias obtenidas respecto a una distribución de referencia t-Student. En la Tabla 6 se muestra de forma compacta el análisis realizado para cada mezcla, donde se indica la hipótesis inicial $\mathrm{HO}$ de igualdad de medias, la hipótesis alternativa $\mathrm{H} 1$ en el caso de no cumplirse la inicial, los grados de libertad $n$ de la distribución de referencia, igual a la suma de datos de las dos muestras menos dos, y el valor de significación $\mathrm{p}$-valor que nos indica si la diferencia es o no significativa. En este sentido, considerando un nivel de confianza de un $95 \%$, se considera que existen diferencias cuando el valor de significación es inferior a 0,05.

Los resultados obtenidos en el análisis estadístico concuerdan con las reflexiones anteriormente dadas. Por un lado, respecto a la resistencia a compresión, sólo existen diferencias significativas cuando la presencia de árido grueso es elevada, mezclas $\mathrm{H} 3$ y H4, y por tanto su orientación tiene especial relevancia. Con respecto al módulo de elasticidad, en ningún caso se detectan diferencias significativas entre ambas direcciones de evaluación.
Lastly, it should be mentioned that addition of silica fume to the mixes leads to an increase in strength of ca. 20\%, as demonstrated by $C 2$ compared to $C 1$, and by $C 4$ compared to $\mathrm{C} 3$.

The trend for modulus of elasticity (Figure 3) is contrary to that for compressive strength. With the exception of mix C2, for which the values in the two directions were nearly equal, all other mixes exhibited greater values in the perpendicular direction than in the parallel direction. However, in all cases these differences were rather small ( $<1 \mathrm{GPa})$, indicating that direction has only a minor influence on modulus of elasticity. These results are consistent with the hypothesis on orientation, as greater values for modulus of elasticity are expected for aggregates oriented perpendicular to the spray direction.

In terms of performance, the concretes mixed according to the proposed proportioning method exhibit similar values for strength and modulus of elasticity as the reference mix, despite requiring $15 \mathrm{~kg}$ less cement. This can be rationalised by the optimisation of the dosing used for these mixes, namely, in achieving a more compact granular skeleton.

\subsection{Statistical analysis}

With the aim of determining if the concretes demonstrated significant differences in their properties in function of the direction of measurement, their mean values for the different parameters were analysed statistically using a Student's t-test reference distribution. Table 6 summarises the analysis for each mix, whereby $\mathrm{HO}$ represents the initial hypothesis of equal means; $C 1$ represents the alternative hypothesis (for the cases in which the initial one was not met); and $n$ represents the degrees of freedom. The $p$-values listed were used to determine significance at a confidence level of 95\%; hence, $p$-values less than 0.05 were considered significant.

The results of the statistical analysis are consistent with the premises stated above. In terms of compressive strength, significance was only observed for differences in mixes containing a high proportion of coarse aggregate (C3 and $\mathrm{C4}$ ); hence the orientation of this aggregate is highly relevant. In terms of modulus of elasticity, no significant differences were observed for any mix in either direction. 
Tabla 6 / Table 6

Análisis estadístico.

Statistical analysis.

\begin{tabular}{|c|c|c|c|c|c|c|c|c|}
\hline \multicolumn{9}{|c|}{ Resistencia a compresión / Compressive strength (MPa) } \\
\hline \multirow[b]{2}{*}{ Mezcla / Mix } & \multicolumn{2}{|c|}{ Paralelo / Parallel (p) } & \multicolumn{2}{|c|}{ Transversal / Perpendicular (t) } & \multirow[b]{2}{*}{ HO } & \multirow[b]{2}{*}{ H1 / C1 } & \multirow[b]{2}{*}{$\mathbf{n}$} & \multirow{2}{*}{$\begin{array}{c}\text { p-valor I } \\
p \text {-value }\end{array}$} \\
\hline & $\begin{array}{c}\text { Media / } \\
\text { Mean }\end{array}$ & $\begin{array}{c}\text { Desv. Est. I } \\
\text { STDV }\end{array}$ & Media / Mean & $\begin{array}{c}\text { Desv. Est. I } \\
\text { STDV }\end{array}$ & & & & \\
\hline $\mathrm{H} 1 / \mathrm{Cl}$ & 34.8 & 4.5 & 34.1 & 2.8 & $p=t$ & $p>t$ & 6 & 0.398 \\
\hline $\mathrm{H} 2 / \mathrm{C} 2$ & 40.5 & 6.0 & 40.0 & 3.2 & $p=t$ & $p>t$ & 10 & 0.436 \\
\hline $\mathrm{H} 3 / \mathrm{C} 3$ & 33.2 & 3.1 & 30.0 & 3.5 & $p=t$ & $p>t$ & 8 & 0.003 \\
\hline $\mathrm{H} 4 / \mathrm{C} 4$ & 47.2 & 3.7 & 36.7 & 7.2 & $p=t$ & $p>t$ & 6 & 0.020 \\
\hline \multicolumn{9}{|c|}{ Módulo de elasticidad / Modulus of elasticity } \\
\hline \multirow[b]{2}{*}{ Mezcla / Mix } & \multicolumn{2}{|c|}{ Paralelo / Parallel } & \multicolumn{2}{|c|}{ Transversal / Perpendicular } & \multirow[b]{2}{*}{ HO } & \multirow[b]{2}{*}{ H1 / C1 } & \multirow[b]{2}{*}{$\mathbf{n}$} & \multirow{2}{*}{$\begin{array}{c}\text { p-valor I } \\
p \text {-value }\end{array}$} \\
\hline & $\begin{array}{c}\text { Media / } \\
\text { Mean }\end{array}$ & $\begin{array}{c}\text { Desv. Est. I } \\
\text { STDV }\end{array}$ & Media / Mean & $\begin{array}{c}\text { Desv. Est. I } \\
\text { STDV }\end{array}$ & & & & \\
\hline $\mathrm{H} 1 / \mathrm{C} 1$ & 26.5 & 2.2 & 28.9 & 2.0 & $p=t$ & $t>p$ & 8 & 0.057 \\
\hline $\mathrm{H} 2 / \mathrm{C} 2$ & 27.4 & 1.7 & 26.8 & 4.0 & $p=t$ & $p>t$ & 13 & 0.355 \\
\hline $\mathrm{H} 3 / \mathrm{C} 3$ & 25.3 & 3.5 & 26.7 & 1.4 & $p=t$ & $t>p$ & 8 & 0.234 \\
\hline $\mathrm{H} 4 / \mathrm{C} 4$ & 27.4 & 2.2 & 28.6 & 3.4 & $p=t$ & $t>p$ & 7 & 0.257 \\
\hline
\end{tabular}

\section{CONCLUSIONES}

Las conclusiones principales que se derivan de los trabajos presentados son:

- El método de dosificación propuesto (3) (6) conduce a resultados satisfactorios, tanto a nivel de ejecución como en las propiedades del hormigón fresco y endurecido en aplicaciones por vía húmeda. Ello abre la vía a una sistematización de la dosificación, superando los planteamientos empíricos existentes en la actualidad.

- Dicho método permite alcanzar prestaciones similares en cuanto a resistencia a compresión, módulo de elasticidad y trabajabilidad, con respecto a un hormigón proyectado dosificado por métodos más empíricos (5), incluso utilizándose menor cantidad de cemento en la composición.

- La dirección de extracción y ensayo de los testigos en relación a la dirección de proyección, influye en la resistencia a compresión de hormigones proyectados por vía húmeda.

- Las resistencias son mayores en la dirección paralela a la proyección, la que se evalúa en la actualidad, con respecto a la transversal, dirección de trabajo real del material en la estructura.

- En este comportamiento que podemos calificar de anisótropo del hormigón proyectado, juegan un papel fundamental los áridos, en particular su forma y cantidad. Respecto al módulo de elasticidad, la tendencia se invierte, con módulos mayores en la dirección transversal, consecuentemente con la orientación predominante del árido, aunque con diferencias mucho menos significativas que en resistencia.

\section{CONCLUSIONS}

The main conclusions reached in this study comprise the following:

- The proposed proportioning method (3 and 6) provides satisfactory performance and results for fresh concrete use and hardening in wet-mix applications. This represents a first step towards systemisation for proportioning to replace the empirical methods used to date.

- Sprayed concrete mixed by the proposed proportioning method has similar compressive strength, modulus of elasticity and workability as a reference sprayed concrete mixed according to more empirical methods (5), yet it requires less cement than the reference composition.

- For wet-mix sprayed concretes the orientation in which samples are extracted and evaluated relative to the spray direction influences the compressive strength.

- Compressive strength is higher parallel to the spray direction, which the usual way for evaluation, than perpendicular to the spray direction, which is the real compressive stress direction of the structure.

- This behaviour, which can be described as anisotropic for sprayed concrete, is highly dependent on aggregates, especially on their shape and quantity. However, the trend is the opposite for modulus of elasticity: greater values are found perpendicular to the spray direction (i.e. in the main orientation of the aggregate). Nonetheless, the differences observed for modulus of elasticity are much less marked than for compressive strength. 


\section{AGRADECIMIENTOS}

Los autores del presente artículo quieren expresar su agradecimiento a la empresa $\mathrm{OHL}$, promotora del estudio realizado, por el soporte brindado para el mismo, y en particular a Juan Carvajal y Miguel Arenas por su activa participación en el desarrollo y seguimiento de los trabajos que han originado el presente artículo.

\section{ACKNOWLEDGEMENTS}

The authors would like to thank the company OHL for sponsoring and assisting with this study, especially Juan Carvajal and Miguel Arenas, for their active participation in developing and following the experiments described here.

\section{BIBLIOGRAFÍA / BIBLIOGRAPHY}

(1) Fernández Cánovas, M.:"Hormigón Proyectado", Cemento y Hormigón, no 877, junio de 2005, pp. 44-57.

(2) Prudencio L. R.: "Contribuçao à dosagem do concreto projetado", Escola Politécnica, Universidade de Sao Paulo, Tesis doctoral (1993).

(3) Rodríguez, J.: "Estudio relativo a la influencia de distintas variables que inciden en la dosificación y puesta en obra del hormigón proyectado", ETS Enginyers de Camins, Canals i Ports de Barcelona, Universitat Politècnica de Catalunya, Tesis doctoral (1997).

(4) Martín Lozano, A.: "Hormigón Proyectado: Análisis de la evolución de la vía seca a la vía húmeda", ETS Enginyers de Camins, Canals i Ports de Barcelona, Universitat Politècnica de Catalunya, Tesina de grado (2003).

(5) American Concrete Institute: Guide to shotcrete, ACI 506R (1990).

(6) García, T.; Agulló, L.; Aguado, A. y Rodríguez, J.: "Propuesta metodológica para dosificación del hormigón proyectado", Hormigón y Acero 220, $2^{\circ}$ trimestre de 2001.

(7) Lascorz, A.: "Estudio relativo al efecto de la incorporación de aditivos químicos de última generación en el hormigón proyectado por vía húmeda", ETS Enginyers de Camins, Canals i Ports de Barcelona, Universitat Politècnica de Catalunya, Tesina de grado (2001).

(8) American Shotcrete Association Q 67: http://www.shotcrete.org/ASAfaqs.htm

(9) AENOR, UNE 83602: "Hormigón y mortero proyectados. Preparación de la muestra para obtención de probetas testigo" (1997).

(10) UNE 83605:"Hormigón y mortero proyectados. Obtención, preparación y ensayo a compresión o tracción de probetas testigo" (1991). 